\title{
An Improved Method for the Detection of Hepatitis C Virus RNA in Plasma Utilizing Heminested Primers and Internal Control RNA
}

\author{
Paul P. Ulrich, Joseph M. Romeo, Lynton J. Daniel, and Girish N. Vyas
}

Department of Laboratory Medicine, University of California, San Francisco, California 94143-0134

The majority of transfusion-associated, non-A, non-B hepatitis cases are caused by hepatitis C virus (HCV), a positive-stranded RNA virus. Although high titers of HCV in clinical specimens have been reported, in some cases extremely low titers of virus are not uncommon. Therefore, an extremely sensitive and reliable assay is required to determine viremia and replication of $\mathrm{HCV}$ accurately. We report here the systematic investigation of factors influencing the detection of HCV RNA by a reverse transcription-polymerase chain reaction (RT-PCR) assay utilizing "drop in-drop out" heminested primers derived from the conserved 5 ' noncoding region of the viral genome. $A$ genetically engineered 5 ' noncoding region has been constructed and used as an internal control. Addition of the control RNA to each test not only allowed semiquantitation of positive reactions but also validated the performance of reverse transcription and PCR for every specimen. The optimized heminested PCR (HN-PCR) protocol is capable of amplifying one molecule of cloned HCV DNA or 10 molecules of in vitro-transcribed $\mathrm{HCV}$ RNA to levels detectable in ethidium bromide-stained agarose gels. We evaluated the improved method for the detection of HCV RNA on a human plasma sample containing the pedigreed strain $\mathrm{H}$ of $\mathrm{HCV}$ with a chimpanzee infectious dose of $10^{6} \%$ $\mathrm{ml}$. Utilizing the internal control RNA, we calculated $2 \times 10^{7}$ virions in $1 \mathrm{ml}$ of the original human plasma.
The HN-PCR achieves the sensitivity and specificity of the double-nested PCR (DN-PCR) in a simplified format that avoids the false-positive results associated with DN-PCR.

1 he polymerase chain reaction (PCR) was discovered in 1985 and has since changed the way nucleic acid analyses are performed in research laboratories. ${ }^{(1)}$ Because of its exquisite sensitivity, PCR has been used for the detection of DNA viruses, retroviruses, and RNA viruses at levels undetectable by conventional molecular hybridization techniques. ${ }^{(2)}$

The recently discovered hepatitis $\mathrm{C}$ virus (HCV) is an important human pathogen and accounts for the majority of transfusion-associated, non-A, non-B hepatitis (NANB) cases worldwide. ${ }^{(3-8)}$ This pathogen is a small, enveloped virus with a positive-stranded RNA genome of approximately $10 \mathrm{~kb} \cdot{ }^{(3)} \mathrm{HCV}$ has a genomic organization and diversity similar to flaviviruses and pestiviruses. ${ }^{(9,10)}$ The genomic RNA encodes a large polypeptide precursor with structural proteins located in the amino-terminal region and a variety of nonstructural proteins in the carboxy-terminal region. Recently, the extreme 5'-terminal regions of several HCV isolates from around the world have been sequenced, and a 341-nucleotide noncoding region with highly conserved nucleotide sequences was revealed. ${ }^{(11,12)}$ These conserved nucleotide sequences are ideal targets for detection of $\mathrm{HCV}$ by reverse transcription (RT)-PCR amplification.
The detection of HCV RNA in blood provides a direct marker of viral replication and infectivity. Although the cloning and analysis of HCV CDNA have led to an improved understanding of $\mathrm{HCV}$ molecular biology, direct study of this virus has been hampered by the unavailability of in vitro techniques for viral propagation and by the lack of a convenient animal model. Therefore, a great deal of attention has been devoted to the development of PCR-based techniques for the detection and characterization of $\mathrm{HCV}$ infections. Due to the low titers of virus that are not uncommon in $\mathrm{HCV}$ infections, ${ }^{(16)}$ many investigators have used a double-nested PCR (DN-PCR) regimen to attain maximum sensitivity. ${ }^{(12-14)}$ We have developed a procedure for the use of "drop in-drop out" heminested $(\mathrm{HN})$ primers $^{(1)}$ derived from the conserved 5 ' noncoding region of $\mathrm{HCV}$ that incorporates the sensitivity of DN-PCR into a simplified format and avoids the potential problems with carry-over that are associated with DNPCR. Furthermore, a comparison of published procedures for RNA purification, reverse transcription, and PCR revealed differences that may affect the sensitivity, specificity, and reported frequency of HCV detection. ${ }^{(12-18)}$ We have systematically investigated factors influencing HCV RNA purification from plasma, HCV cDNA synthesis, and PCR amplification. We have also incorporated an internal control RNA and the PCR carryover prevention methodology into the optimized RT-PCR assay and established the overall sensitivity for the detection of $\mathrm{HCV}$. 


\section{MATERIALS AND METHODS}

\section{Purification of Viral RNA from Plasma}

Two procedures were used to concentrate virus from plasma. Ultracentrifugation (UC): $8.5 \mathrm{ml}$ of precleared plasma (centrifugation at $3000 \mathrm{~g}$ for $30 \mathrm{~min}$ at $4^{\circ} \mathrm{C}$ ) was layered over $4 \mathrm{ml}$ of $20 \%$ sucrose/10 mM Tris (pH 7.5)/1 mM EDTA in a sealable ultracentrifugation tube and centrifuged for $2 \mathrm{hr}$ at $46,000 \mathrm{rpm}$ (model 50Ti rotor, Beckman Instruments) at $4^{\circ} \mathrm{C}$. The supernatant was carefully aspirated, the tubes were inverted, and the inside was dried with a cotton.

Polyethylene glycol precipitation (PEG): $225 \mu \mathrm{l}$ of $21 \%$ PEG 6000/1.5 M $\mathrm{NaCl}$ were added to $450 \mu \mathrm{l}$ plasma. After $1 \mathrm{hr}$ on ice, the samples were centrifuged $\left(15,000 \mathrm{~g}, 30 \mathrm{~min}, 4^{\circ} \mathrm{C}\right)$ and the supernatant was aspirated.

RNA extraction: The standard buffer for RNA extraction (UNSET) consisted of $8 \mathrm{M}$ urea, $0.15 \mathrm{M} \mathrm{NaCl}, 2 \%$ SDS, $0.1 \mathrm{~mm}$ EDTA, and $0.1 \mathrm{~m}$ Tris (pH 7.5). ${ }^{(16)}$ An aliquot of $450 \mu$ l of plasma was added to UNSET 1 ( 0.48 gram urea, $0.1 \mathrm{ml}$ of $20 \%$ SDS, $0.1 \mathrm{ml}$ of $1 \mathrm{~m}$ Tris, $\mathrm{pH} \mathrm{7.5,30 \mu l} 5 \mathrm{M}$ $\mathrm{NaCl}, 2 \mu \mathrm{l} 0.5 \mathrm{M}$ EDTA) that was preheated to $40^{\circ} \mathrm{C} ; 60 \mu \mathrm{l}$ of plasma was added to $340 \mu$ l of preheated UNSET 2 solution $(0.48$ gram urea, $0.1 \mathrm{ml}$ of $20 \%$ SDS, $0.1 \mathrm{ml}$ of $1 \mathrm{M}$ Tris, pH 7.5, $30 \mu \mathrm{l} 5 \mathrm{M}$ $\mathrm{NaCl}, 2 \mu \mathrm{l}$ of $0.5 \mathrm{M}$ EDTA, $390 \mu \mathrm{l}$ of $\mathrm{H}_{2} \mathrm{O}$ ); and the UC or PEG pellets were resuspended in $400 \mu \mathrm{l}$ of preheated UNSET 3 solution (0.48 gram urea, $0.1 \mathrm{ml}$ of $20 \%$ SDS, $0.1 \mathrm{ml}$ of $1 \mathrm{M}$ Tris, pH 7.5, $30 \mu \mathrm{l} 5 \mathrm{M}$ $\mathrm{NaCl}, 2 \mu \mathrm{l} 0.5 \mathrm{M}$ EDTA, $450 \mu \mathrm{l} \mathrm{H}_{2} 0$ ). The samples were vigorously vortexed, extracted three times with equal volumes of phenol/chloroform/isoamyl alcohol (25:24:1), and precipitated by centrifugation $(15,000 \mathrm{~g}, 30 \mathrm{~min}$, room temperature) from the aqueous phases with 1 volume of isopropanol. The pellets were dissolved in $\mathrm{DEPC}-\mathrm{H}_{2} \mathrm{O}$, precipitated in $0.3 \mathrm{M} \mathrm{NaOAC}$ with 2.5 volumes of ethanol by centrifugation, air dried, and resuspended in DEPC- $\mathrm{H}_{2} \mathrm{O}$.

A buffer incorporating guanidinium isothiocyanate (GITC) as the chaotropic agent ${ }^{(19)}$ was also used and achieved comparable results. In our experience, UNSET buffer yielded more consistent results and marginally better sensitivity than GITC buffer (data not shown). However, the slight advantages of UNSET are somewhat compromised by the requirement that UNSET buffer be freshly prepared for each use while GITC buffer stock solutions are stable at room temperature for over 1 month.

\section{Oligonucleotides}

All oligonucleotides were synthesized at the Biomolecular Resource Center at the University of California, San Francisco, using cyanoethylphosphoramidite chemistry on the Applied Biosystems Inc. 380B Synthesizer. The oligonucleotides were deblocked in concentrated ammonium hydroxide at $55^{\circ} \mathrm{C}$ for $10 \mathrm{hr}$, purified on NENSORB resin (NEN, Boston, MA), analyzed by HPLC chromatography using MonoQ HR/R columns (Pharmacia, Alameda, CA), and run in $\mathrm{NaOH}(\mathrm{pH} \mathrm{12}$ ) and a $0.5-1.0 \mathrm{M} \mathrm{NaCl}$ gradient. $^{(20)}$

\section{Recombinant HCV Plasmids}

The transcription vector $\mathrm{pC} 280.2$ was engineered by cloning a 192-bp fragment from the 5 ' noncoding region of $\mathrm{HCV}$ into the EcoRI site of pTZ18U (Biorad, Richmond, CA). The HCV fragment had been amplified with the primer pair JR12-JR19 (Table 1) from the plasma of a single anti-HCV positive, ALT-elevated blood donor \#280, and it was then li-

TABLE 1 Oligonucleotides Used for Cloning, Reverse Transcription, Amplification, and Hybridization of the 5' Noncoding Region of HCV

\begin{tabular}{lccl}
\hline Primers & Position $^{\text {a }}$ & Polarity & \multicolumn{1}{c}{ Sequence } \\
\hline JR 12 & $1-20$ & + & GGCGACACTCCACCATAGAT \\
JR 13 & $34-53$ & + & GGAACTACTGTCTTCACGCA \\
JR 14 & $141-160$ & - & GCAATTCCGGTGTACTCACC \\
JR 19 & $197-216$ & - & CGCCCAAATCTCCAGGCATT \\
JR 26 & $1-31$ & + & GGCGACACTCCACCATAGATCACTCCCCTGT \\
JR 28 & $162-192$ & - & GGGTTGATCCAAGAAAGGACCCGGTCGTCCT \\
\hline
\end{tabular}

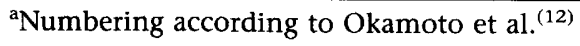

gated to EcoRI adaptors with standard methods. ${ }^{(21)}$

The internal control plasmid pC280.3 was engineered by cloning a 71-bp DNA insert consisting of parts of the pTZ18U and pBluescript SK (Stratagene, La Jolla, $\mathrm{CA}$ ) polylinkers into the SmaI site at position 114 of the $\mathrm{HCV}$ portion of pC280.2. Figure 1 shows the position of the $\mathrm{HCV}$ primers and the length of the amplified DNA.

\section{In Vitro Transcription of HCV RNA}

The transcription plasmids pC280.2 and pC280.3 were linearized with Scal to yield RNA of about $1.4 \mathrm{~kb}$. Following in vitro transcription with T7 RNA polymerase, ${ }^{(21)}$ template DNA was digested with DNase I (Promega Biotech, Madison, WI) and RNA was purified by Sephacryl S400 spin column chromatography (Pharmacia LKB, Piscataway, NJ). The purified 1.4-kb RNA was quantitated by spectrophotometry, and $1 \mathrm{OD}_{260}$ was considered to be equivalent to $40 \mu \mathrm{g} / \mathrm{ml}$ of RNA or $1.3 \times 10^{6}$ molecules per $1 \mathrm{pg}$. RNA dilutions were prepared into DEPCtreated $1 \mathrm{~mm}$ HEPES buffer ( $\mathrm{pH} 7.5$ ) containing $1 \mu \mathrm{g} / \mathrm{ml}$ of tRNA and stored in aliquots at $-70^{\circ} \mathrm{C}$.

\section{Reverse Transcription}

Aliquots of $10 \mu$ l of RNA were primed with either 10 pmoles of random hexamers $[p(d N) 6$, Pharmacia-LKB Biotechnology] or with 10 pmoles of the HCV-specific oligonucleotide JR28 in Moloney murine leukemia virus (Mo-MLV) reverse transcriptase buffer (Bethesda Research Laboratories, Gaithersburg, MD), $1 \times$ Taq buffer, or avian myeloblastosis virus (AMV) reverse transcriptase buffer (Boehringer Mannheim). cDNA was synthesized in a $20-\mu$ l volume containing $0.5 \mathrm{~mm}$ of each dNTP, $10 \mathrm{~mm}$ DTT, 20 units of RNase inhibitor (Boehringer Mannheim), and 200 units of Mo-MLV or 40 units of AMV reverse transcriptase. For random priming, the RT mixture was incubated at room temperature for 10 min, followed by $37^{\circ} \mathrm{C}$ for $1 \mathrm{hr}$. For priming with JR 28 , the RT mixture was incubated for $1 \mathrm{hr}$ at $37^{\circ} \mathrm{C}$.

\section{RNA Degradation}

Two principally different approaches were employed to degrade RNA after cDNA synthesis. 

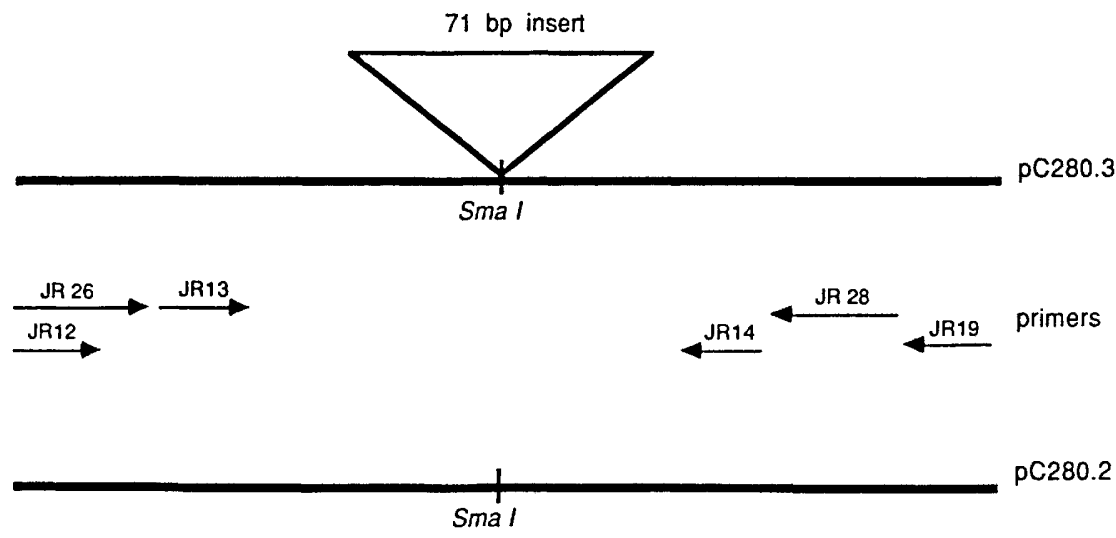

0

50

100

150

200 base pairs

FIGURE 1 Schematic drawing of the cloned $5^{\prime}$ terminus of HCV (pC280.2) and the cloned internal control (pC280.3). The arrows represent position, orientation, and relative size of the HCVspecific primers. JR26, JR13, and JR28 are the primers for the drop in-drop out HN-PCR procedure; primers for DN-PCR are JR12 and JR19 for the first amplification and JR13 and JR14 for the second.

1. Enzymatic. To $20 \mu \mathrm{l}$ of RT mix, we added $1 \mu$ l of RNase $H$ (Bethesda Research Laboratories) diluted to 0.5 unit/ $\mu l$ in $1 \times$ Taq buffer and incubated at $37^{\circ} \mathrm{C}$ for $40 \mathrm{~min}$, followed by $90^{\circ} \mathrm{C}$ for 5 min. Alternatively, $1 \mu$ l of RNase D (DNase-free, Boehringer Mannheim) diluted to $50 \mathrm{ng} / \mu \mathrm{l}$ in $1 \times$ Taq buffer was added to $20-\mu \mathrm{l}$ RT reactions incubated at $94^{\circ} \mathrm{C}$ for 2 min followed by $37^{\circ} \mathrm{C}$ for 5 $\min$.

2. Chemical. Because Mo-MLV buffer has a high buffer capacity $(50 \mathrm{~mm}$ Tris, pH 8.3), we used only $1 \times$ Taq buffer with $3 \mathrm{mM} \mathrm{MgCl}_{2}$ for the RT reaction in this experiment. To $20 \mu \mathrm{l}$ of RT mix containing $1 \times$ Taq buffer, we added $1 \mu \mathrm{l}$ of 20 $\mathrm{mm} \mathrm{NaOH}$, incubated at $60^{\circ} \mathrm{C}$ for $1 \mathrm{hr}$ and neutralized with $1 \mu \mathrm{l}$ of $20 \mathrm{~mm} \mathrm{HCl}$.

\section{PCR Experiments}

The DNA or cDNA preparations were amplified in a final volume of $50 \mu \mathrm{l}$ in a DNA thermal cycler (Perkin-Elmer Cetus Corp., Norwalk, CT). The amplification mixture contained 1.5 units of AmpliTaq (Perkin-Elmer Cetus Corp., Norwalk, CT), 0.04-50 pmoles of each primer, 200

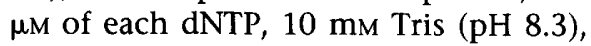
1-8 $\mathrm{mM} \mathrm{MgCl}_{2}, 50 \mathrm{~mm} \mathrm{KCl}$, and $200 \mu \mathrm{g}$ / ml gelatin. ${ }^{(22)}$

For HN-PCR the thermal cycler was programmed for the first 20 cycles to allow amplification only with the primer pair JR26-JR28: The thermal profile was $94^{\circ} \mathrm{C}$ for $30 \mathrm{sec}$ to denature DNA and $70^{\circ} \mathrm{C}$ for $30 \mathrm{sec}$ to anneal and extend primers. After 20 cycles, the annealing temperature was dropped to allow annealing of the inner upstream primer JR13 and amplification with the primer pair JR13-JR28 in the following 40 cyles: The thermal profile was $94^{\circ} \mathrm{C}$ for $30 \mathrm{sec}$, $56^{\circ} \mathrm{C}$ for $30 \mathrm{sec}$, and $72^{\circ} \mathrm{C}$ for $30 \mathrm{sec}$.

The PCR Carry-over Prevention kit (Perkin-Elmer Cetus Corp., Norwalk, CT) was used as suggested by the manufacturer. We investigated increasing dUTP concentrations $(200,400,600,800$, and $1,000 \mu \mathrm{M}$ ) with an equimolar increase in $\mathrm{MgCl}_{2}$ concentration to determine optimal amplification efficiency. After amplification, the samples were soaked at $72^{\circ} \mathrm{C}$ and then extracted with chloroform to inactivate uracil $\mathrm{N}$-glycosylase. An aliquot of $15 \mu$ l of PCR reaction mixtures was electrophoresed through $3 \%$ or $4 \%$ agarose gels ( $1 \%$ SeaKem and $2 \%$ to $3 \%$ NuSieve, FMC Corp., Rockland, ME).

\section{Detection of HCV RNA in Human Plasma}

Strain H plasma was taken from a multiply transfused patient. Infectivity titer for NANB hepatitis was determined to be at least $10^{6} / \mathrm{ml}$ in chimpanzees. ${ }^{(23)}$ Serial 10-fold dilutions of strain $\mathrm{H}$ plasma were prepared in normal human plasma that was negative for anti-HCV and did not reveal HCV RNA after RT-PCR. Aliquots of $50 \mu \mathrm{l}$ were added to $350 \mu \mathrm{l}$ of UNSET 2 containing internal control RNA and 5 $\mu \mathrm{g}$ of tRNA. After three phenol/chloroform extractions and two ethanol precipitations, the pellets were resuspended in $50 \mu \mathrm{l}$ of DEPC- $\mathrm{H}_{2} \mathrm{O}$. Aliquots of $10 \mu \mathrm{l}$ (containing 20 or 200 molecules of internal control RNA) were reverse-transcribed in duplicates, treated with RNase $\mathrm{H}$ as described, and amplified by $\mathrm{HN}$ PCR. Aliquots of $15 \mu \mathrm{l}$ of PCR reaction mixture were separated on a $4 \%$ agarose gel and stained by ethidium bromide.

\section{Southern Blot Hybridization}

Agarose gels were soaked twice for 15 min in $0.5 \mathrm{M} \mathrm{NaOH} / 1.5 \mathrm{M} \mathrm{NaCl}$ with shaking and then transferred with $20 \times$ SSC onto a nylon membrane (Genatren 45, Plasco Inc., Woburn, MA) overnight. ${ }^{(21)}$ The membranes were exposed to UV light for $10 \mathrm{~min}$ to cross-link DNA, prehybridized in $6 \times \mathrm{SSPE}, 5 \times$ Denhardt's, $0.4 \%$ SDS for $2 \mathrm{hr}$ at $42^{\circ} \mathrm{C}$, and hybridized under the same conditions for 6-8 hr in the presence of JR14 endlabeled with $\gamma^{-}{ }^{32} \mathrm{P} .{ }^{(24)}$ The membranes were washed twice at room temperature and once at $42^{\circ} \mathrm{C}$ with $6 \times$ SSPE $/ 0.1 \%$ SDS, then air-dried and exposed for $2 \mathrm{hr}$ and $12 \mathrm{hr}$ to XAR-5 film (Eastman Kodak Co., Rochester, NY).

\section{RESULTS}

\section{HCV DNA Amplification}

In this drop in-drop out HN-PCR protocol, two long outer primers (with the upstream primer in limiting concentration) and one short inner primer are present in the initial reaction mix. The thermal cycler is programmed to allow the two outer primers but not the inner primer to amplify the target initially. During these amplification steps, the limiting concentration of upstream primer is depleted. This is followed by a set of amplification cycles at a decreased annealing temperature, which allows annealing of the shorter inner primer and the downstream primer with amplification of the target and also the initial PCR products (Fig. 1).

We used 1000 molecules of the recombinant $\mathrm{HCV}$ plasmid pC280.2 to optimize the HN-PCR amplification parameters. The plasmid DNA was linearized with EcoRI and used as a template for amplification with either the primer pairs JR26-JR28 or JR13-JR28 (Table 1). Based on thermodynamic consider- 


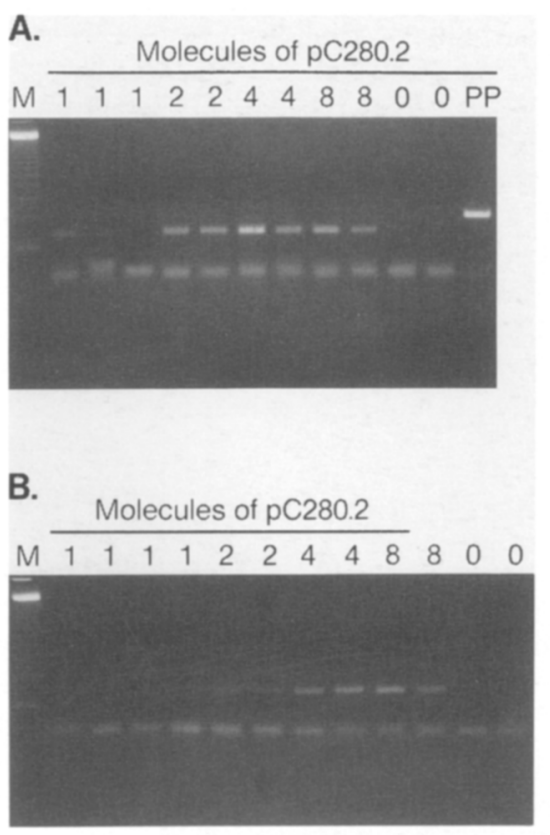

FIGURE 2 Representative picture demonstrating the sensitivity of the HN-PCR assay for the detection of cloned HCV DNA (pC280.2; 158bp amplified DNA) in a $3 \%$ agarose gel stained with ethidium bromide. Serial twofold dilutions of cloned HCV DNA were amplified with either dTTP $(A)$ or dUTP $(B)$. Molecular size marker (M) is 123-bp ladder. For the PCR positive control (PP), PCR was performed on 10 molecules of cloned pC280.3 DNA to generate a 229-bp amplified product.

ations, the long HCV primers JR26-JR28 were annealed at $70^{\circ} \mathrm{C}$ and the primer pair JR13-JR28 was annealed at $56^{\circ} \mathrm{C}$. At these annealing temperatures, a $\mathrm{MgCl}_{2}$ titration $(2,4,6$, and $8 \mathrm{~mm})$ was performed. These experiments indicated optimal amplification with these two primer pairs in the presence of $2 \mathrm{~mm}$ $\mathrm{MgCl}_{2}$ under the specified temperature conditions (data not shown). The primer pair JR13-JR28 was also tested at an annealing temperature of $70^{\circ} \mathrm{C}$ and did not support exponential amplification at this annealing temperature.

The reaction mixture contained all three primers for HN-PCR: JR13 and JR28 were present in a concentration of 500 fmoles $/ \mu \mathrm{l}$, and the outer upstream primer JR26 was used in limiting concentrations analogous to the strategy of asymmetric PCR. ${ }^{(2)}$ On the basis of our experience with DN-PCR, the concentration of the original outer primers had to be decreased below $20 \mathrm{fmoles} / \mu \mathrm{l}$ to achieve maximal sensitivity in the secondary amplification. Limiting concentrations of 20,4 , and 0.8 fmoles $/ \mu \mathrm{l}$ of
JR26 were used together with 500 fmoles/ $\mu$ l of JR13 and JR28 to amplify 10,1000 , or 100,000 molecules of linearized pC280.2 DNA. A limiting concentration of $4 \mathrm{fmoles} / \mu \mathrm{l}$ for the outer primer JR26 was optimal: It supported amplification of 10 molecules of pC280.2 as efficiently as fivefold higher concentrations but did not show multiple DNA bands with 100,000 molecules of target DNA (data not shown).

The optimized parameters for $\mathrm{HN}$ PCR were used to amplify $1,2,4$, or 8 molecules of the EcoRI-cut plasmid 280.2 diluted into tRNA-containing Taq buffer. Figure $2 \mathrm{~A}$ shows a representative picture of an ethidium bromide-stained agarose gel. Two of three amplifications with one molecule and two of two amplifications with two, four, or eight molecules were positive. Hybridization of the amplified DNA after Southern transfer to a membrane was performed for all samples (Fig. 2A and Table 2) and revealed the same result. From the Poisson distribution of successful amplifications with limiting amounts of HCV DNA target (Fig. 2A and Table 2), we deduce singlecopy sensitivity of the HN-PCR protocol. $^{(22)}$

To guard against false-positive results, we adapted the PCR carry-over prevention method to our HN-PCR protocol. We amplified 10 and 100 molecules of 280.2 DNA and found a colinear increase of DNA yield with increasing concentrations of dUTP up to $800 \mu \mathrm{M}$ (data not shown). With $800 \mu \mathrm{M}$ dUTP and $2.6 \mathrm{~mm}$ $\mathrm{MgCl}_{2}$, we determined the sensitivity of the HN-PCR assay by amplifying one, two, four, or eight molecules of 280.2 DNA. As shown in Figure 2B, one molecule of target DNA did not yield a visible signal and two molecules amplified to a lesser extent as compared to amplifica-

TABLE 2 Detection Frequency of Successful Amplifications on Limiting Amounts of Cloned HCV DNA in Ethidium Bromide-Stained Agarose Gels

\begin{tabular}{cccccc}
\hline & \multicolumn{5}{c}{ Molecules of cloned HCV DNA } \\
\cline { 2 - 6 } Plasmid & 0 & 1 & 2 & 4 & 8 \\
\hline pC280.2 & & & & $3 / 3$ & $3 / 3$ \\
dTTP & $0 / 6$ & $4 / 6$ & $3 / 3$ & $3 / 3$ & $3 / 3$ \\
dUTP & $0 / 6$ & $1 / 6$ & $3 / 3$ & & $3 / 3$ \\
pC280.3 & & & & $3 / 3$ & $3 / 3$ \\
dTTP & $0 / 6$ & $3 / 6$ & $3 / 3$ & $3 / 3$ \\
dUTP & $0 / 6$ & $0 / 6$ & 5
\end{tabular}

Either dTTP or dUTP was used for amplification in the HN-PCR assay. The results are depicted as the ratio of successful amplifications to total number of amplifications. tions with dTTP. Southern blot hybridization revealed one positive amplification with one molecule of target DNA. These results indicate that after optimization of dUTP and $\mathrm{MgCl}_{2}$ concentrations, the amplification efficiency and thus sensitivity of PCR is slightly decreased with the PCR carry-over prevention method.

Amplifications of the internal control with either dTTP or dUTP. Table 2 summarizes the results. No difference in amplification efficiency between wild-type size (pC280.2) and the internal control (pC280.3) HCV DNA was observed.

\section{Competition of Internal Control and Cloned HCV DNA During Coamplification}

Because the internal control DNA has the same primer binding sites as the target, competition for primer binding can occur and affect sensitivity of the assay. Serial 10-fold dilutions of cloned HCV DNA were coamplified with 10 molecules (Fig. 3A) or 100 molecules (Fig. 3B) of internal control DNA. In the presence of 10 molecules of internal control DNA, two of five amplifications with one molecule and two of two amplifications with $10,10^{2}, 10^{4}$, or $10^{6}$ molecules of cloned HCV DNA were amplified to detectable levels. The presence of 100 molecules of internal control DNA decreased the detection limit for cloned HCV DNA about 10-fold. All four amplifications with one molecule and two of two amplifications with 10 molecules of cloned HCV DNA were negative; 100 and more molecules of cloned HCV DNA were consistently positive. These results indicate that the amount of internal control DNA or cDNA has to be within one order of magDNA (pC280.3) were also performed 

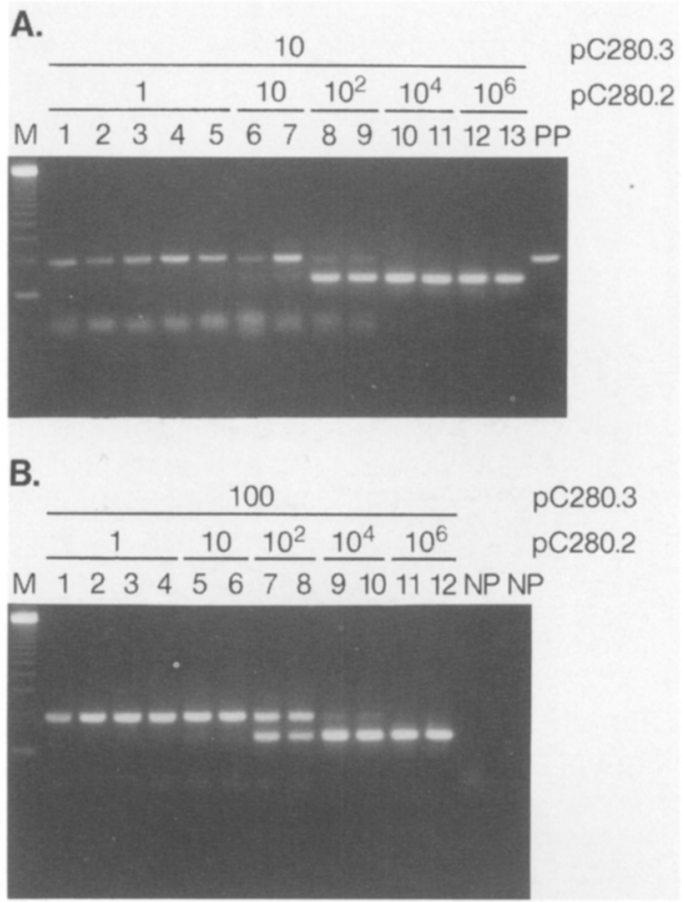

FIGURE 3 Coamplification of cloned HCV DNA (pC280.2; 158-bp amplified DNA) and internal control DNA (pC280.3; 229-bp amplified DNA). Serial 10-fold dilutions of cloned HCV DNA ( 1 , $10,10^{2}, 10^{4}$, and $10^{6}$ molecules of pC280.2) were coamplified with either 10 molecules of internal control DNA (pC280.3; $A$ ) or 100 molecules of internal control DNA $(B)$ by HN-PCR and separated on a $4 \%$ agarose gel. (Lanes $N P$ ) negative (no DNA) PCR control; (lane PP) positive control as described in the legend to Fig. 2.

nitude of the target DNA before amplification. Furthermore, the extent of the amplification process, the DNA yield, varies more with lower than with higher

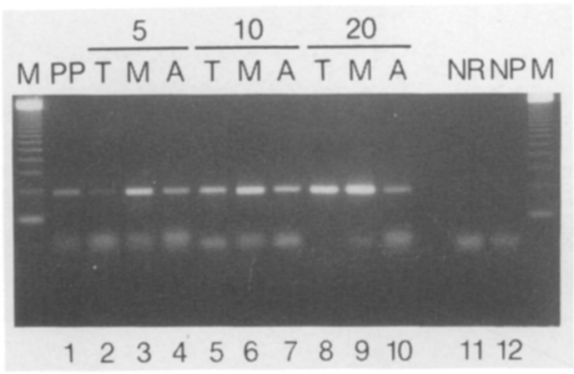

FIGURE 4 Influence of different reverse transcriptases and $\mathrm{RT}$ reaction volumes on the detection limit of HCV cDNA. An aliquot of 400 molecules of 280.3 RNA was primed with random hexamers, reverse-transcribed in $40 \mu \mathrm{l}$ and then $5 \mu \mathrm{l}$ (lanes 5), $10 \mu \mathrm{l}$ (lanes 10), or 20 $\mu \mathrm{l}$ (lanes 20) were amplified in a $50 \mu \mathrm{l}$ PCR reaction. Amplified DNA (15 $\mu \mathrm{l})$ was separated on a $3 \%$ agarose gel and visualized with ethidium bromide. (Lanes T) Mo-MLV in Taq buffer; (lanes $M$ ) Mo-MLV in Mo-MLV buffer; (lanes $A$ ) AMV in AMV buffer; (lanes $P P$ ) PCR internal control; (lane NR) RT negative control; (lanes NP) PCR negative control; (lane $M$ ) 123-bp marker. amounts of target DNA: 10 molecules compared with 100 molecules of internal control (Fig. 3A, lanes 1-7 compared with Fig. 3B, lanes 1-8). These findings emphasize the need of an internal control for the quantitation of low amounts of target DNA.

\section{Reverse Transcription}

Two reverse transcriptases are currently commercially available: a native enzyme purified from avian myeloblastosis virus (AMV) and a recombinant enzyme from Moloney murine leukemia virus (MoMLV) expressed in Escherichia coli. Both enzymes differ in their buffer requirements and AMV has a higher intrinsic RNase $\mathrm{H}$ activity than Mo-MLV. We reverse-transcribed internal control RNA (280.3) with Mo-MLV in either Taq buffer or Mo-MLV buffer, and, alternatively, we used AMV in AMV buffer. An aliquot of 5,10 , or $20 \mu \mathrm{l}$ of RT mixture (containing 50, 100, or 400 molecules of HCV RNA) was amplified by HN-PCR (Fig. 4). Amplified DNA was electrophoresed through an agarose gel, and the staining intensity of the DNA re- vealed that reverse transcription under Mo-MLV conditions has a positive effect on PCR amplification (Fig. 4, lanes 3,6, and 9). In contrast, reverse transcription under AMV conditions indicated inhibition of PCR. More HCV RNA in a larger volume of AMV buffer did not result in more amplified DNA (Fig. 4, lanes 4, 7, and 10).

\section{Priming of HCV CDNA}

The specificity and sensitivity of the RTPCR assay can be affected by the method of cDNA priming and by the choice of carrier nucleic acids present in the reverse transcription reaction. We primed internal control RNA with either random hexamers (Fig. 5, lanes 1-4) or with the HCV-specific oligonucleotide JR28 (Fig. 5, lanes 5-8) and reverse-transcribed with Mo-MLV in the absence (lanes 1 and 5) or in the presence of different types of carrier nucleic acids. In samples containing a large excess of nontarget, heterologous DNA, cDNA priming with the HCV-specific oligonucleotide generated more nonspecifically amplified DNA than cDNA priming with random hexamers. With JR28-priming, the nonspecific DNA almost completely obscured the specific DNA band, whereas the random-primed cDNA revealed the specific signal (Fig. 5, lanes 2 and 6). For either priming method, rRNA as a carrier showed the specific DNA fragment but also a significant amount of nonspecific cDNA (lanes 3 and 7). The strongest spe-

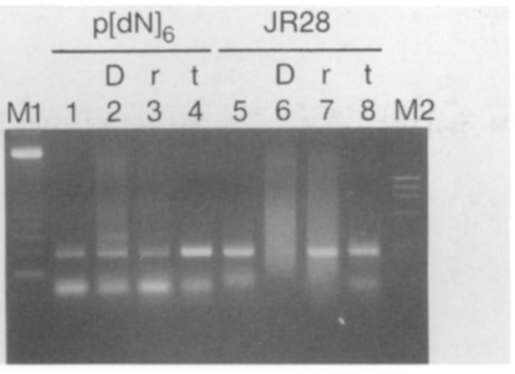

FIGURE 5 Influence of cDNA priming and type of carrier nucleic acid on RT-PCR. 280.3 RNA was primed either with random hexamers $\left[\mathrm{p}(\mathrm{dN})_{6}\right]$, or specific $\mathrm{HCV}$ primers (JR28) in the absence (lanes 1 and 5) or in the presence of $1 \mu \mathrm{g}$ carrier nucleic acid (lanes $2,3,4$, and $6,7,8$ ). RNA was reverse-transcribed with MoMLV, amplified by HN-PCR, and then electrophoresed through a $3 \%$ agarose gel. (Lanes $D$ ) Salmon sperm DNA; (lanes $r$ ) E. coli ribosomal RNA; (lanes $t$ ) E. coli RNA; (lane M1) 123-bp marker; (lane M2) $\phi \mathrm{X} / \mathrm{Hae}$ III marker. 


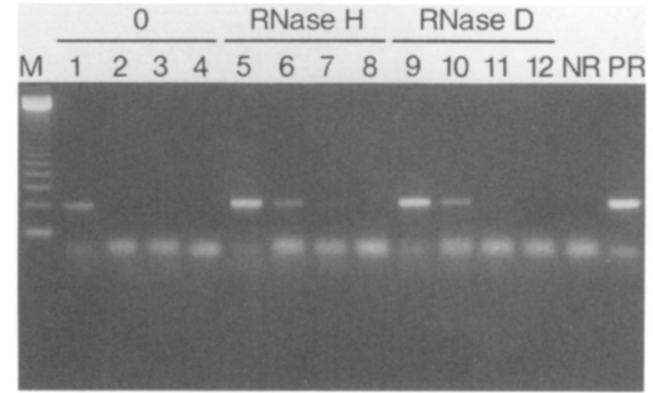

FIGURE 6 Sensitivity of RT-PCR with and without RNA degradation after the RT reaction. 280.3 RNA was reverse-transcribed, and fivefold serial dilutions of the RT reaction (250 molecules in lanes 1, 5, 9; 50 molecules in lanes 2, 6, 10; 10 molecules in lanes 3, 7, 11; and 2 molecules in lanes $4,8,12$ ) were amplified without (lanes $O$ ) or after RNA degradation [with either RNase $\mathrm{H}$ or a heterogeneous mixture of DNase-free RNases (RNase D)]. (Lane $M$ ) 123-bp, marker; (lane NR) negative; (lane $P R$ ) internal control for reverse transcription.

cific DNA band, and consequently the most specific amplification, was seen with random-primed cDNA and tRNA as a carrier (Fig. 5, lane 4).

\section{RNA Degradation}

The PCR amplification of cDNA has been reported to be less efficient than DNA amplification. ${ }^{(25)}$ We addressed the question of whether the HCV RNA in the HCV cDNA/RNA heteroduplex interferes with amplification, resulting in decreased sensitivity of the RT-PCR assay, and if so, whether degradation of that RNA will facilitate cDNA amplification. Fivefold serial dilutions $(250,50,10$, and 2 molecules) of $280.3 \mathrm{RNA} / \mathrm{cDNA}$ heteroduplex were amplified with the HN-PCR protocol without and after RNA degradation. As presented in Figure 6, without

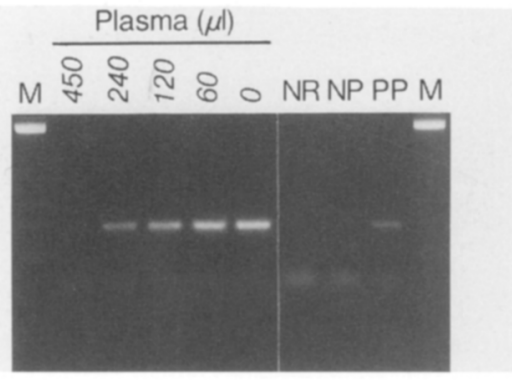

FIGURE 7 Decreased sensitivity of the RT-PCR assay due to inhibitors from plasma. Different volumes of normal (anti-HCV negative) plasma $(450,240,120$, and $60 \mu \mathrm{l})$ were processed with UNSET and phenol/chloroform. RNA (100 molecules of 280.3) was added to the ETOH pellets, reverse-transcribed with random hexamers and Mo-MLV, amplified with HN-PCR, and then separated on a $3 \%$ agarose gel.
RNA degradation, 250 molecules gave a strong signal, whereas after RNA degradation with either RNase $H$ or RNase D, 50 molecules gave a strong signal. On the original gel and picture, a weak DNA band could be seen in Figure 6 (lanes 2, 7 , and 11). These data indicate about fivefold increase in sensitivity of the RTPCR assay with RNA degradation and, furthermore, that RNase D can substitute for RNase $H$, a rather expensive enzyme. However, to achieve similar results, the RT mixture containing RNase D had to be heated to $94^{\circ} \mathrm{C}$ for $2 \mathrm{~min}$, then cooled to $37^{\circ} \mathrm{C}$ for $5 \mathrm{~min}$ for a total of three cycles. One or two cycles resulted in a less sensitive RT-PCR assay. As an alternative to enzymatic RNA degradation, chemical RNA hydrolysis with alkaline $\mathrm{pH}$ and heat was evaluated. The chemical treatment revealed comparable results to the enzymatic treatment: 10 and more molecules of target DNA were positive.

\section{RNA Preparation}

We determined the effects of different purification procedures of $\mathrm{HCV}$ RNA from plasma on the sensitivity of the RTPCR assay. Different volumes of normal plasma $(450,240,120$, and $60 \mu \mathrm{l})$ were resuspended in UNSET buffer containing tRNA. After two phenol/chloroform extractions, 100 molecules of internal control RNA was added to the ETOH pellets, reverse-transcribed, and amplified. The results (Fig. 7) demonstrate that preparations from $60 \mu \mathrm{l}$ plasma do not significantly interfere with the RT-PCR assay, whereas preparations from more plasma result in a decreased DNA yield after RT PCR. To quantitate the inhibitory effect, we processed aliquots of 60 and $450 \mu$ of plasma, added serial twofold dilutions of internal control HCV RNA, and performed RT-PCR. We also analyzed pellets from PEG-precipitation $(450 \mu \mathrm{l}$ of plasma) and ultracentrifugation ( $2 \mathrm{ml}$ of plasma) in the same way. The results were compared with the RT-PCR results obtained with an equal number of in vitro-transcribed internal control RNA molecules (Table 3). The RT-PCR assay performed on RNA purified from $60 \mu \mathrm{l}$ of plasma or from UC pellets of $2 \mathrm{ml}$ of plasma was able to detect 20 molecules of internal control RNA; this was only two-fold less sensitive than RT-PCR performed on pure, in vitro-transcribed RNA. A total of five phenol/chloroform extractions and three ethanol precipitations did not improve sensitivity, indicating that the inhibition is not caused by proteins. Plasma volumes of $450 \mu \mathrm{l}$ with or without PEG precipitation were strongly inhibitory in the RT-PCR assay, and the detection limit for HCV RNA was decreased more than 1000-fold. These data emphasize the importance of pure HCV RNA for ultimate sensitivity of the RT-PCR assay

\section{Quantitation of HCV RNA in a Human Plasma Containing Strain H of HCV}

A human plasma had been titrated for

TABLE 3 Influence of Different Purification Procedures of HCV RNA from Plasma on the Sensitivity of RT-PCR ${ }^{\mathrm{a}}$

\begin{tabular}{lcccccc}
\hline $\begin{array}{l}\text { Molecules } \\
\text { of } 280.3\end{array}$ & & \multicolumn{2}{c}{$\begin{array}{c}\text { Plasma } \\
(\mu \mathrm{l})\end{array}$} & & \multicolumn{2}{c}{$\begin{array}{c}\text { Plasma } \\
\text { pellet }\end{array}$} \\
RNA & Pure & 60 & 450 & & PEG & UC $^{\mathrm{b}}$ \\
\hline 5120 & NT $^{\mathrm{c}}$ & NT & ++ & ++ & NT \\
2560 & NT & NT & ++ & +- & NT \\
1280 & NT & NT & ++ & -- & NT \\
640 & NT & NT & -- & -- & NT \\
320 & NT & NT & -- & -- & NT \\
160 & NT & NT & NT & & NT & ++ \\
80 & ++ & ++ & NT & & NT & ++ \\
40 & ++ & ++ & NT & & NT & ++ \\
20 & ++ & ++ & NT & & NT & ++ \\
10 & ++ & -- & NT & & NT & +- \\
\hline
\end{tabular}

${ }^{a}$ The results in duplicates are shown: ++ , both amplifications positive; -- , both amplifications negative; +- , one amplification positive, one amplification negative.

bultracentrifugation.

'Not tested. 


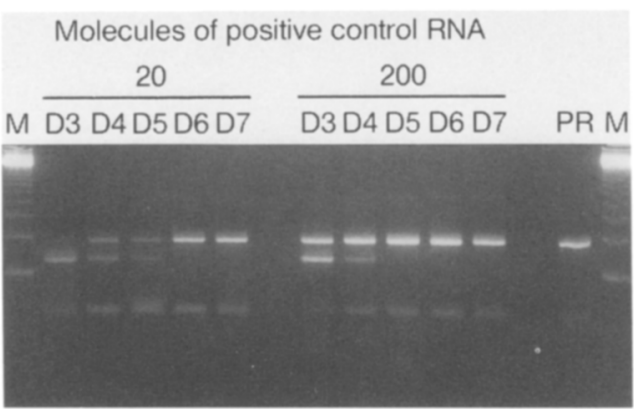

FIGURE 8 Detection and semiquantitation of HCV RNA (strain H) in the presence of an internal control RNA (200 molecules of 280.3). (Lane D3) $10^{-3}$; (lane D4) $10^{-4}$; (lane D5) $10^{-5}$; (lane D6) $10^{-6}$; (lane $D 7$ ) $10^{-7}$ dilution of the original human plasma. (Lane $P R$ ) RNA positive control (20 copies of pC280.3 RNA); (lane $M$ ) 123-bp ladder marker.

infectivity for NANB hepatitis and was reported to have a chimpanzee infectious dose of at least $10^{6} / \mathrm{ml}$. Serial 10 fold dilutions of the plasma were prepared. Figure 8 presents the results of the RT-PCR assay after separation of the amplified DNA on an ethidium bromidestained agarose gel. In the presence of 200 molecules of internal control RNA, the dilutions $10^{-3}$ and $10^{-4}$ of the original human plasma were positive for HCV RNA and $10^{-5}, 10^{-6}$, and $10^{-7}$ were negative. Using only 20 molecules of internal control, the dilution $10^{-5}$ was also positive for HCV RNA. These results indicate competition between target and internal control RNA in the RTPCR assay, causing a decrease in sensitivity. In addition, as observed in Figure 3 for DNA, low amounts of target cDNA result in more variable amplifications than higher amounts of cDNA, emphasizing the need of an internal control for quantitation. Because the $10^{-4}$ dilution gave the same amount of amplified DNA as 20 molecules of internal control RNA (Fig. 8, D4), we concluded that 20 molecules of HCV RNA are present in 10 $\mu l$ of the $10^{-4}$ dilution; similarly, the $10^{-3}$ dilution gave the same amount of amplified DNA as 200 molecules of the internal control RNA, indicating 200 molecules of internal control RNA in 10 $\mu \mathrm{l}$ of the $10^{-3}$ dilution (Fig. 8, D3). This translates into $2 \times 10^{7}$ virions in $1 \mathrm{ml}$ of the original plasma.

\section{DISCUSSION}

We have performed a systematic investigation of factors that affect the sensitivity and specificity of the RT-PCR procedure for the detection of HCV RNA from plasma. To aid in our studies, we have engineered a vector from which positive control RNA can be generated. The HCV sequences of this RNA are derived from a highly conserved region of the HCV genome and contain heterologous sequences inserted between the binding sites of our amplification primers so that a distinct signal is obtained following reverse transcription and PCR amplification. This RNA control has proven to be extremely useful in the optimization of our protocols by providing a convenient source of a fully characterized RNA.

Moreover, this RNA is a crucial reagent for the quantitation of target RNA. The data in Table 2 suggest that there is no significant difference in the amplification efficiencies of target and internal control. Therefore, coamplification of the two species can yield accurate determinations of the initial number of target molecules. Because the internal control can be included in every reaction, it provides a method for monitoring the sample-to-sample variation that occurs in procedures as complex as RNA preparation and RT-PCR. Furthermore, successful amplification of the internal control RNA gives more meaning to negative results and provides a precise detection limit for every assay. A parameter that has not been addressed in our studies is the reverse transcription efficiency of the internal control RNA versus that of the native viral RNA. Our analyses assume that these efficiencies are not significantly different but, due to the unavailability of known quantities of native viral RNA, this assumption cannot be tested.

In our experience, the procedure of RNA preparation from plasma is one of the most critical factors in determining the final sensitivity of the assay; this as- sertion is based on the coamplification of internal control RNA with RNA purified by a variety of methods from clinical material. We evaluated the effectiveness of the acid guanidinium isothiocyanate/phenol/chloroform extraction $^{(19)}$ as well as the use of a commercially available kit for RNA purification (RNaid Kit protocol). We found that the recovery of ${ }^{32} \mathrm{P}$-labeled RNA, the incorporation of ${ }^{32} \mathrm{P}$-labeled nucleotides into CDNA, and the sensitivity of RT-PCR were modestly but consistently superior with the UNSET procedure we have described. Thus, denaturation of $60 \mu \mathrm{l}$ of plasma in UNSET buffer, followed by phenol/chloroform extraction and alcohol precipitation, has been found to be a rapid screening procedure that maintains excellent RT-PCR sensitivity (Table 3). However, larger plasma volumes $(120,240$, and $450 \mu \mathrm{l})$ show a negative correlation with the sensitivity of the RTPCR assay, if the final volume of the solution is held constant (Fig. 7). The decreased sensitivity appears to be mainly the result of the copurification of inhibitors from plasma, because control experiments have shown that the loss of ${ }^{32}$ P-labeled RNA in the above-mentioned procedure was only between 10 and $20 \%$ in all cases (unpublished data). Thus, it appears that the stoichiometry of the initial volume of plasma to the final extraction volume is an important parameter in determining the final sensitivity of the assay: $60 \mu \mathrm{l}$ is the maximum plasma volume that should be processed by our method in a standard $1.7-\mathrm{ml}$ microcentrifuge tube.

If more than $60 \mu \mathrm{l}$ of plasma is to be analyzed, an ultracentrifugation step is recommended. Using this method, RNA from $2 \mathrm{ml}$ of plasma can be analyzed with little or no compromise in sensitivity (Table 3 ). However, in addition to being expensive, time consuming, and labor intensive, ultracentrifugation also introduces, in spite of all precautions (e.g., sealable ultracentrifugation tubes) a significant risk for cross-contamination. This risk can be minimized by screening out high-titer $\mathrm{HCV}$ plasma units with the 60- $\mu$ l RNA purification procedure and only subjecting the negative units to ultracentrifugation.

For maximum sensitivity, we have found certain features of the cDNA synthesis reaction to be particularly relevant. In our studies, the best sensitivity was obtained when cDNA synthesis was 
primed by random hexamers in the presence of carrier tRNA using Mo-MLV reverse transcriptase. It should be noted, however, that in our comparison of random and specific priming, the same "downstream" primer was used for both cDNA synthesis and the subsequent PCR. The large amount of nonspecific DNA generated from amplification of cDNA primed with the HCV-specific oligonucleotide (Fig. 5) is probably the result of the relaxed annealing conditions of the cDNA synthesis reaction; this could lead to promiscuous priming of reverse transcription and generate nonspecific cDNA products containing a perfect primer binding site for one of the PCR primers. However, specific priming of cDNA synthesis can yield results comparable with random priming if the cDNA synthesis primer binding site is located downstream of the region to be amplified subsequently (unpublished results). Following cDNA synthesis, degradation of the template RNA in the RNA/cDNA heteroduplex increases the amplification efficiency of our PCR protocol at least fivefold. RNA degradation can be achieved in one of three ways, each having its own advantages and disadvantages. Incubation with DNase-free RNases is inexpensive and effective, but it introduces the potential for contamination of purified HCV RNA before reverse transcription which could yield false negative results. Another inexpensive approach is chemical RNA degradation; the disadvantage is in one additional pipetting step. Consequently, although currently more expensive, we prefer RNase $\mathrm{H}$ because its easy to use and specifically digests RNA in RNA/DNA duplexes.

The use of heminested primers introduces a significant improvement in the ease and accuracy with which the RTPCR assay can be employed. Because $\mathrm{HCV}$ is often present in blood in very low titers, some investigators have employed DN-PCR to achieve ultimate sensitivity. (12-14) However, in addition to doubling the work load, DN-PCR has the intrinsic risk of cross-contaminating the secondary amplifications with product from the primary amplifications, resulting in a much higher rate of false-positive reactions. Such contamination cannot be circumvented by the currently available carry-over prevention methodology because it cannot be used in the primary amplifications, due to its principle of operation.
All of these disadvantages are overcome by HN-PCR without compromising the sensitivity of the amplification reaction. The use of heminested primers from the $5^{\prime}$ noncoding region of the $\mathrm{HCV}$ genome is capable of single-copy sensitivity without the use of radioactive materials (Fig. 2). Yet a HN-PCR mixture is as easy to prepare as a conventional PCR mixture and does not entail the increased risk of carry-over that is associated with DN-PCR.

To demonstrate the performance of these methods, we have applied them to the quantitation of $\mathrm{HCV}$ in a well-characterized human plasma. This specimen was reported to have a chimpanzee infectious dose of at least $10^{6} / \mathrm{ml}$; our results suggest an HCV RNA titer of approximately $2 \times 10^{7} / \mathrm{ml}$. Consequently, based on our estimate of RNA titer, the chimpanzee infectious dose is approximately 20 virions from this particular $\mathrm{HCV}$ isolate. It is important to mention that this specimen was stored under optimal conditions, defrosted only once, and immediately processed as suggested by Busch et al. ${ }^{(26)}$

In conclusion, we have investigated a number of variables important for $\mathrm{HCV}$ RNA purification from plasma, cDNA synthesis, and amplification. We present here an optimized assay system that incorporates as its most salient features the use of a drop in-drop out HN-PCR protocol along with an internal positive control for the detection of HCV RNA with ultimate sensitivity and specificity.

\section{ACKNOWLEDGMENT}

This research was supported by NHLBI Program Project grant PO1 HL-36589.

\section{REFERENCES}

1. Ehrlich, H.A., D.H. Gelfand, and J.J. Sninsky. 1991. Recent advances in the polymerase chain reaction. Science 252: 16431651.

2. Innis, M.A., D.H. Gelfand, J.J. Sninsky, and T.J. White. 1990. PCR protocols: A guide to methods and applications. Academic Press, San Diego, CA.

3. Choo, Q.-L., G. Kuo, A.J. Weiner, L.R. Overby, D.W. Bradley, and M. Houghton. 1989. Isolation of a cDNA clone derived from a blood-borne non-A, non-B viral hepatitis genome. Science 244: 359-362.

4. Kuo, G., Q.-L. Choo, H.J. Alter, G.L. Gitnick, A.G. Redeker, R.H. Purcell, T. Miyamura, J.L. Dienstag, M.J. Alter, and C.E.
Stevens. 1989. An assay for circulating antibodies to a major etiologic virus of human non-A, non-B hepatitis. Science 244: $362-364$.

5. van der Poel, C.L., H.W. Reesink, P.N. Lelie, A. Leentvaar-Kuypers, Q.-L. Choo, G. Kuo, and M. Houghton. 1989. Antihepatitis $C$ antibodies and non- $A$, non- $B$ post-transfusion hepatitis in the Netherlands. Lancet ii(8658): 297-298.

6. Kuhnl, P., S. Seidl, W. Stangel, J. Beyer, W. Sibrowski, and J. Flik. 1989. Antibody to hepatitis $C$ virus in German blood donors (letter). Lancet ii(8658): 324.

7. Esteban, J.I., L. Viladomiu, A. Gonzalez, M. Roget, J. Genesca, R. Esteban, et al. 1989. Hepatitis $\mathrm{C}$ virus antibodies among risk groups in Spain. Lancet ii(8658): 294-297.

8. Alter, H.J., R.H. Purcell, J.W. Shih, J.C. Melpolder, M. Houghton, Q.-L. Choo, and G. Kuo. 1989. Detection of antibody to hepatitis $C$ virus in prospectively followed transfusion recipients with acute and chronic non-A, non-B hepatitis. New Engl. J. Med. 321: 1494-1500.

9. Miller, R.H. and R.H. Purcell. 1990. Hepatitis $C$ virus shares amino acid sequence similarity with pestiviruses and flaviviruses as well as members of two plant virus supergroups. Proc. Natl. Acad. Sci. 87: 2057-2061.

10. Choo, Q.-L., K.H. Richman, J.H. Han, K. Berger, C. Lee, C. Dong, C. Gallegos, D. Coit, R. Medina-Selby, and P.J. Barr. 1991. Genetic organization and diversity of the hepatitis C virus. Proc. Natl. Acad. Sci. 88: 2451-2455.

11. Han, J.H., V. Shyamala, K.H. Richman, M.H. Brauer, B. Irvine, M.S. Urdea, P. Tekamp-Olson, G. Kuo, Q.L. Chou, and M. Houghton. 1991. Characterization of the terminal regions of hepatitis $C$ viral RNA: Identification of conserved sequences in the $5^{\prime}$ untranslated region and poly(A) tails at the $3^{\prime}$ end. Proc. Natl. Acad. Sci. 88: 1711-1715.

12. Okamoto, H., S. Okada, Y. Sugiyama, S. Yotsumoto, T. Tanaka, H. Yoshizawa, F. Tsuda, Y. Miyakawa, and M. Mayumi. 1990. The 5'-terminal sequence of the hepatitic C virus genome. Japan J. Exp. Med. 60: 167-177.

13. Kaneko, S., M. Unoura, K. Kobayashi, K. Kuno, S. Murakami, and N. Hattori. 1990. Detection of serum hepatitis $C$ virus RNA (letter). Lancet 335: 976.

14. Garson, J.A., R.S. Tedder, M. Briggs, P. Tuke, J.A. Glazebrook, A. Trute, D. Parker, J.A. Barbara, M. Contreras, and S. Aloysiuso. 1990. Detection of hepatitis C viral sequences in blood donations by "nested" polymerase chain reaction and prediciton of infectivity. Lancet 335: 1419-1422.

15. Ohkoshi, S., H. Kato, T. Kinoshita, M. Hijikata, Y. Ohtsuyama, N. Okazaki, H. 
Ohkura, S. Hirohashi, A. Honma, and T. Ozaki. 1990. Detection of hepatitis C virus RNA in sera and liver tissues of non-A, non-B hepatitis patients using the polymerase chain reaction. Jpn J. Cancer Res. 81: 862-865.

16. Ulrich, P.P., J.M. Romeo, P.K. Lane, I. Kelly, L.J. Daniel, and G.N. Vyas. 1990. Detection, semiquantitation, and genetic variation in hepatitis $C$ virus sequences amplified from the plasma of blood donors with elevated alanine aminotransferase. J. Clin. Invest. 86: 1609-1614.

17. Weiner, A.J., G. Kuo, D.W. Bradley, F. Bonino, G. Saracco, C. Lee, J. Rosenblatt, et al. 1990. Detection of hepatitis C viral sequences in non-A, non-B hepatitis. Lancet 335: 1-3.

18. Farci, P., H.J. Alter, D. Wong, R.H. Miller, J.W. Shih, B. Jett, and R.H. Purcell. 1991. A long-term study of hepatitis $C$ virus replication in non-A, non-B hepatitis. New Engl. J. Med. 325: 98-104.

19. Chomczynski, P. and N. Sacchi. 1987. Single-step method of RNA isolation by acid guanidinium thiocyanate-phenol-chloroform extraction. Anal. Biochem. 162: 156159.

20. Ivanetich, K.M., J. Akiyama, and D.V. Santi. 1991. Automated purification of synthetic oligonucleotides. Biotechniques 10: 704-707.

21. Ausubel, F.M, R. Brent, R.E. Kingston, D.D. Moore, J.G. Seidman, J.A. Smith, and K. Struhl. Current protocols in molecular biology. Wiley, New York.

22. Saiki, R.K., D.H. Gelfand, S. Stoffel, S.J. Scharf, R. Higuchi, G.T. Horn, K.B. Mullis, and H.A. Erlich. 1988. Primer-directed enzymatic amplification of DNA with a thermostable DNA polymerase. Science 239: 487-491.

23. Feinstone, S.M., H.J. Alter, H.P. Dienes, Y. Shimizu, H. Popper, D. Blackmor, D. Sly, W.T. London, and R.H. Purcell. 1981. Non-A, non-B hepatitis in chimpanzees and marmosets. J. Infect. Dis. 144: 588598.

24. Ulrich, P.P., R.A. Bhat, B. Seto, D. Mack, J.J. Sninsky, and G.N. Vyas. 1989. Enzymatic amplification of hepatitis B virus DNA in serum compared with infectivity testing in chimpanzees. J. Infect. Dis. 160: $37-43$.

25. Rappolee, D.A., A. Wang, D. Mark, and Z. Werb. 1989. Novel method for studying mRNA phenotypes in single or small numbers of cells. J. Cell. Biochem. 39: 1-11.

26. Busch, M.P., J.C. Wilber, P. Johnson, L. Tobler, and C.S. Evans. Impact of specimen handling and storage on detection of hepatitis $C$ virus RNA. Transfusion 32: $420-425$. 


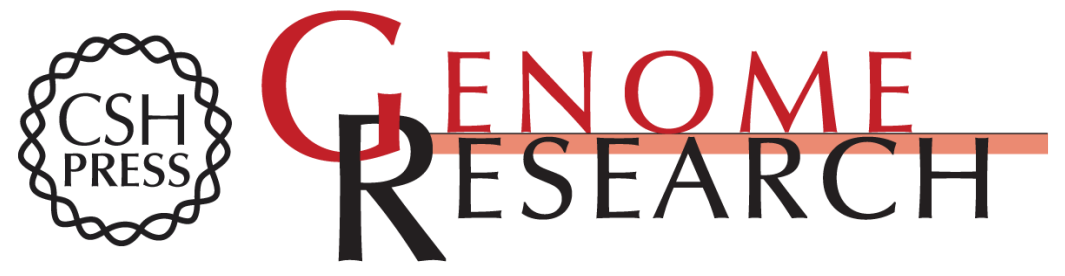

\section{An improved method for the detection of hepatitis C virus RNA in plasma utilizing heminested primers and internal control RNA.}

P P Ulrich, J M Romeo, L J Daniel, et al.

Genome Res. 1993 2: 241-249

Access the most recent version at doi:10.1101/gr.2.3.241

References This article cites 20 articles, 7 of which can be accessed free at:

http://genome.cshlp.org/content/2/3/241.full.html\#ref-list-1

\section{License}

Email Alerting Receive free email alerts when new articles cite this article - sign up in the box at the Service top right corner of the article or click here.

\section{Affordable, Accurate Sequencing.}

